\title{
Seed Production of Knolkhol (Brassica oleracea var. Gongylodes) under Mid Hills of Jammu \& Kashmir, India
}

\author{
Anil Bhushan*, Satesh Kumar, Susheel Sharma, Vikas Sharma, \\ Manoj Kumar and Kamlesh Bali
}

Regional Agricultural Research Station, Rajouri, SKUAST-Jammu-185131, India

*Corresponding author

\begin{tabular}{|l|}
\hline Ke y w o r d s \\
Knol khol, Seed \\
production, Mid \\
hills
\end{tabular}

\section{A B S T R A C T}

Knol khol (Brassica oleracea var. Gongylodes L.) is one of the important cruciferous vegetable crops of mid hills of Jammu \& Kashmir. It is a short duration crop, biennial showing seed maturiy in the month of April-May.Its maturity coincides with the sowing of maize crop which is the main staple crop of the region. To enable the farmers to go for knolkhol seed production, a two year field experiment was conducted at Regional Agricultural Research Station, Rajouri, SKUAST-Jammu during 2011-12 and 2012-13. Two methods viz., in-situ and replanting methods of knolkhol seed production were laid out and all the growth, seed yield and crop duration parameters were recorded for comparative studies.Results clearly pointed out that that in situ method, seed was produced in the month of March, where as in replanting method, the seed was produced in the month of April. Moreover, high seed yield per plant and test weight was recorded in situ method. Thus, it can be concluded that in situ method of knolkhol seed production may be recommended to the farmers of mid hills of Jammu \& Kashmir.

\section{Introduction}

Knol khol (Brassica oleracea var. Gongylodes L.) is one of the important cruciferous vegetable crops of state of Jammu \& Kashmir, India. It is mainly a cool season crop but grows well even throughout the year. It is traditionally grown extensively in Kashmir valley. However, over a period of time its popularity and acceptability has increased manifold across Jammu region of the state also. Due to this reason its cultivation has extended to all the nooks and corners of the state. In Jammu province, it is cultivated in $2712 \mathrm{ha}$ area with production of 55118 MT (Anonymous, 2017).There is a tremendous scope of knol khol production in Jammu region particularly in the Mid hills of 
Jammu and Kashmir due to highly favourable climatic conditions with mild agroclimates suited for its cultivation as well as seed production (Bhushan et al, 2010). Besides being preferred for its long tender leaves, fleshy enlarged stem formed just above ground commonly known as knob, is the edible portion and is used as cooked vegetable at tender age and for pickle purpose when the knobs become fibrous. The modified stem (knob) of knol khol is fairly rich in carbohydrates, proteins, vitamin $\mathrm{C}$ and important minerals like calcium, phosphorous, potassium and sodium (Banu Shalini et al, 2002).

The importance of quality seed which is able to produce the desired crop is well known. In this direction, method of seed production also plays a key role to gurantee the desired crop performance and economic returns to the farmers. There are two methods of seed production in knol khol viz., in situ (seed to seed method) and replanting (knob to seed method). While the former method is mainly followed for commercial seed production, the later method is followed for nucleus or breeder seed production (Singh et al, 1959). For quality seed production in cole crops it requires low temperature (vernalization) for change of vegetative stage to reproductive stage (Verma and Sharma, 2000). Knol khol is sensitive to bolting known as premature bolting which is common problem in seed crop. The duration of vernilization period also effects bolting and it has been established that the vernilization effect decreases when this period lasts longer than a certain number of days (Verma and Sharma, 2000).However, seed production is mainly done in winter months only in plains as well as in hills. The agro-climate of Jammu region is quite suitable for seed production of knolkhol. However, its maturity coincides with the sowing of maize crop which is the main staple crop of the region. To enable the farmers to go for knolkhol seed production, a two year field experiment was carried out under mid hill conditions of Jammu \& Kashmir.

\section{Materials and Methods}

\section{Location and climate}

A two year field experiment was carried out during Rabi season of the year 2011-12 and 2012-13 at Experimental Farm of Regional Agricultural Research Station, Rajouri, SKUAST-Jammu. The experimental farm is situated at $32.52^{0} \mathrm{~N}$ latitude and $74.01^{\circ} \mathrm{E}$ longitude at an elevation of $958 \mathrm{~m}$ above mean sea level. The place experiences hot dry summers, humid rainy season and extended winter season. The topography of the place is predominantly hilly and undulating. The soil of the experimental field was clayey in texture with $196.5 \mathrm{~kg} / \mathrm{ha}$ available $\mathrm{N}, 8.1 \mathrm{~kg} / \mathrm{ha}_{2} \mathrm{O}_{5}$, $124 \mathrm{~kg} / \mathrm{ha}$ available $\mathrm{K}_{2} \mathrm{O}$ and having a $\mathrm{pH}$ of 7.67. The knol khol variety ' $\mathrm{G}-40$ ' developed by SKUAST-Jammu, having ability to produce seeds under diverse agroclimates ranging from subtropical plains to mid and high hills of Jammu and Kashmir was used for experimentation

\section{Nursery raising}

Seeds were sown in the $\mathrm{I}^{\mathrm{st}}$ week of September on the raised nursery beds ( $3 \mathrm{~m} \times 1 \mathrm{~m}$ size) in lines $5 \mathrm{~cm}$ apart. Healthy seedlings were ready for transplanting after 4 weeks of sowing. Seedlings were transplanted on $\mathrm{I}^{\text {st }}$ week of October during both the years.

\section{Crop raising}

Three ploughings were done to bring the field into fine tilth and well rotten farm yard manure (FYM) @ 20t/ha was incorporated 15 days before actual transplanting and rest of inorganic fertilizers were applied at the rate of $100 \mathrm{~kg} \mathrm{~N}, 50 \mathrm{~kg} \mathrm{P}_{2} \mathrm{O}_{5}$ and $50 \mathrm{~kg}$ MOP as per 
the recommendations in package of practices of vegetables crops (Anonymous,2018). 1/3 ${ }^{\text {rd }}$ dose of $\mathrm{N}$ and full doses of $\mathrm{P}_{2} \mathrm{O}_{5}$ and MOP were applied as basal dose. Remaining $2 / 3^{\text {rd }}$ of $\mathrm{N}$ was top dressed in two equal amounts after 30 and 45 days of transplanting. An additional dose of $50 \mathrm{~kg} \mathrm{~N}, 50 \mathrm{~kg} \mathrm{P}_{2} \mathrm{O}_{5}$ and 50 $\mathrm{kg}$ MOP with crop, whereas as given to the in situ crop. All the other intercultural operations were carried out as per recommended in the package of practices.

\section{Seed production methods}

To check relative efficiency for quality seed production of the knolkhol, two methods viz.,in-situ and replanting method were tested.

\section{In situ method}

Healthy, uniform true to type plants were selected from the main field and were allowed to grow, overwinter and produce seed in the field itself.

\section{Replanting method}

A separate field was selected where the selected knobs were replanted in the pits of $1 \times 1$ feet size, dug at the spacing of 1 meter apart. Pits were filled with well rotten FYM and N P K and selected plants were replanted in the last week of November. During replanting, all the leaves except crown leaves, were removed and lifted with mud ball carefully without disturbing the root zone. All the necessary plant protection measures were taken from time to time to ward off any chance of diseases and pests. Data from both the methods was recorded for various plant and seed traits viz., plant height $(\mathrm{cm})$, number of branches, days to $50 \%$ flowering, crop duration, number of siliqua per plant, length of siliqua $(\mathrm{cm})$, number of seeds per siliqua, 100 seed weight $(\mathrm{mg})$ and seed yield per plant (g) during the experimentation and comparison was done from average data of both the years.

\section{Results and Discussion}

From the perusal of results reflected in Table 1 , it was revealed that maximum plant height $(134.6 \mathrm{~cm})$ and number of branches (14.0) was recorded in in situ method which was $31.2 \mathrm{~cm}$ and 2.2 higher than replanting method (103.4cm and 11.8). The plants also showed 50 percent flowering after 131 days of transplanting which was 22.9 days earlier than replanting method (156.0 days). The seed crop raised through in situ method took 175 days to mature which was 22.0 days earlier than replanting method (197 days). Earliness in the seed maturity under in situ method was crucial to the farmers of mid hill region of J\&K to go for timely maize planting. Similar results were obtained by Kaki,2010 in knolkhol under Jammu subtropical plains.

Higher average seed yield per plant was also recorded in in situ method with $54.8 \mathrm{~g}$ which was $17.1 \mathrm{~g}$ more than replanting method (37.7 g). The increased seed yield in in situ method can be attributed to high values of seed yield contributing parameters. Maximum number of siliqua per plant, siliqua length and number of seeds per siliqua $(305.2,7.3 \mathrm{~cm}$ and 19.8 respectively) was recorded in in situ method as compared to replanting method (257.9, $6.4 \mathrm{~cm}$ and 14.8 respectively) (Table 1 , Fig 1 ). The obvious reason for high seed parameters in situ method might be due to fact that in replanting method the plant was subjected to transplanting shock and also took additional days for re-establishment. Similar results were obtained by Kaki,2010 in knolkhol under Jammu subtropical plains and Mohanty and Srivastava, 2002 in cauliflower .

Quality of seed was also found better in in situ method with high values of 1000 seed weight $(4.70 \mathrm{~g})$ as compared to replanting 
method $(3.80 \mathrm{~g})$. Bold seed formation in in situ method can be attributed to the overall better growth contributing parameters and undisrupted life cycle of the plant. Similar findings were reported by Mohanty and Srivastava, 2002 in cauliflower.

Table.1 Comparison of seed production methods of knol khol under mid hill conditions of Jammu \& Kashmir (Data based on average of two years)

\begin{tabular}{|l|c|c|}
\hline Parameter & In situ method & Replanting method \\
\hline Plant height (cm) & 134.6 & 103.4 \\
\hline No. of branches/plant & 14 & 11.8 \\
\hline Days to 50\% flowering & 131 & 156 \\
\hline Seed crop duration & 175 & 197 \\
\hline No. of siliqua/plant & 305.2 & 257.9 \\
\hline Length of siliqua (cm) & 7.3 & 6.4 \\
\hline No. of seeds/siliqua & 19.8 & 14.8 \\
\hline 1000 seed weight (g) & 4.70 & 3.80 \\
\hline Seed yield /plant (g) & 54.8 & 37.7 \\
\hline
\end{tabular}

Fig.1 Comparison of Pod size in in situ and replanting method

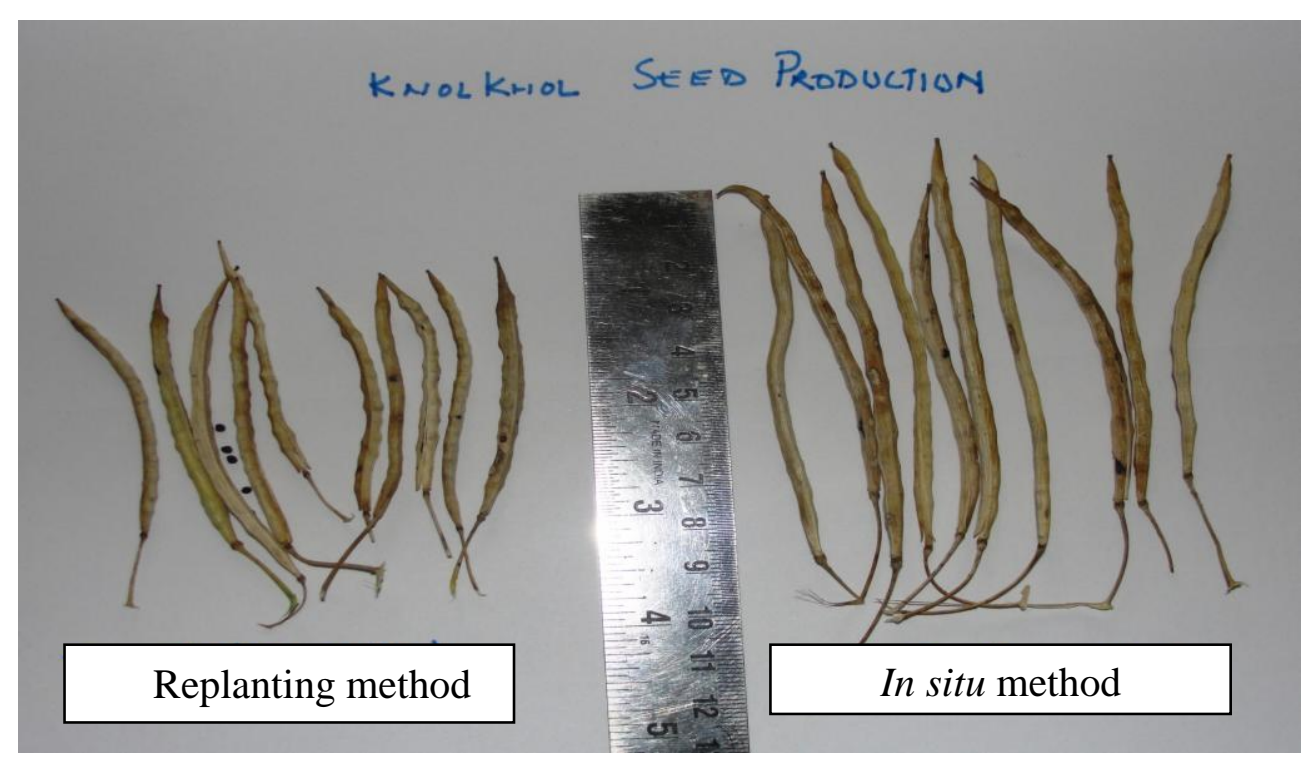

Therefore, based on the results obtained in the experiment, it can be concluded that in situ method, seed was produced earlier with high seed yield per plant and test weight as compared to replanting method and may be recommended to the farmers of mid hills of Jammu \& Kashmir. 


\section{References}

Anonymous, 2017. Annual Area and Production Data. Directorate of Agriculture, J\&K, Jammu.

Anonymous, 2018.Package of Practices of Vegetable crops. Directorate of Extension, SKUAST-Jammu.

BanuShalini S., Channel, H.T., Hebrur, N.S., Dharmatti, P.R. and Sarangamath, P.A. 2002. Effect of integrated nitrogen management on nutrient uptake in knolkhol, yield and nutrient availability in soil. Karnataka $J$. Agric. Sci. 15(1): 43-46

Bhushan, A., Sharma, A. K and Sharma, J .P. (2010). Integrated nutrient management in knolkhol under $\mathrm{J} \& \mathrm{~K}$ conditions. Journal of Research, SKUAST-J. 9(2): 240-243

Kaki Ranjeet (2010). Studies on transplanting dates and methods of seed production in knolkhol (Brassica oleracea var. gongyloides L.). MSc. Thesis. Division of Vegetable Science \& Floriculture, FoA, Main campus, Chatha, J\&K (India).

Mohanty, S. and Srivastava, B.K. (2002). Effect of time of planting and method of crop raising on seed production of Pant Shubra mid season cauliflower (Brassica oleracea var botrytis sub var cauliflora). Indian Journal of Agricultural Sciences. 72 (6): 350-352

Singh, H.B., Thakur, M.R. and Bhagchandani, P.M. (1959). Vegetable Seed production in Kullu Valley-I. Indian Journal of Horticulture. 16(2): 92-101.

Verma, T.S. and Sharma, S. C. (2000). Producing seeds of biennial vegetables in temperate regions. Directorate of Information and Publications, Ministry of Agriculture, ICAR, New Delhi. 64-71.

\section{How to cite this article:}

Anil Bhushan, Satesh Kumar, Susheel Sharma, Vikas Sharma, Manoj Kumar and Kamlesh Bali. 2020. Seed Production of Knolkhol (Brassica oleracea var. Gongylodes) under Mid Hills of Jammu \& Kashmir, India. Int.J.Curr.Microbiol.App.Sci. 9(08): 521-525. doi: https://doi.org/10.20546/ijcmas.2020.908.059 